\title{
White Tea a Day Keeps Disease Away: A Review
}

\author{
Harshal A Pawar* \\ Assistant Professor and HOD, Dr. L. H. Hiranandani College of Pharmacy, India
}

Submission: April 14, 2018; Published: July 02, 2018

*Corresponding author: Harshal A Pawar, Assistant Professor and HOD (Quality Assurance), Dr. L. H. Hiranandani College of Pharmacy, Ulhasnagar - 421003, Maharashtra, India, Tel: +91-8097148638; Email: hapkmk@rediffmail.com / harshal.dlhhcop@gmail.com

\begin{abstract}
White tea is a rare tea that is obtained from the same plant (Camellia sinensis) as green, oolong and black tea. It is derived from silvery buds and young leaves of the plant. The leaves are hand-picked, steamed and dried without further processing. It is the least processed tea among all the teas available in the market. Minimum processing result in the preservation of high amounts of phytochemicals that confers many health benefits. This present review provides a general overview of the origin, processing, phytochemistry and the potential health promoting benefits of white tea.
\end{abstract}

Keywords: White tea; Antioxidants; Catechin; Polyphenols

\section{Introduction}

Nutraceuticals have received considerable interest because of their presumed safety and potential nutritional and therapeutic effects. Pharmaceutical and nutritional companies are aware of the monetary success taking advantage of the more health-seeking consumers and the changing trends resulting in a proliferation of such value-added products aimed at heart health to cancer.

Tea is one of the most popular beverages worldwide. Tea has been used as medicine for centuries [1,2]. Now modern science is discovering what people in China and throughout the world have long known that the tea is good for us. White tea is the least processed tea and has the highest antioxidant levels [3]. Originating from and predominantly produced in southern China, it was virtually unknown to the western world until the late 1800s.

The plant Camellia sinensis (Family: Theaceae) yields white, green and black tea [4]. White tea is an unfermented tea made from young shoots of Camellia sinensis protected from sunlight to avoid polyphenol degradation. Being the least processed tea, white tea has the high total polyphenol content. Its supreme power is in preventing disease and disorder. White tea protects against cancer, heart disease, and stroke, the leading causes of death in the industrial world, as well as numerous other conditions. There are four main varieties of white tea which includes Silver Needle, White Peony, Long Life Eyebrow, and Tribute Eyebrow [5,6]. The present review provides a general overview of the origin, processing, phytochemistry and the potential health promoting benefits of white tea.

\section{Process of Preparation of White Tea}

White tea is made from the buds of the tea plant. Unlike black or green tea, white tea is not rolled, and only slightly oxidized, making it the least processed tea. White tea belongs to the group of tea that does not require panning, rolling or shaking. Plucking of young tea leaves with much fine hair can produce good-quality white tea. The leaves and buds are allowed to wither in natural sunlight before they are lightly processed to prevent oxidation or further tea processing. It is steam dried quickly after the leaves are picked- there is no oxidation at all. Because there is no oxidation, it contains the most anti-oxidants and catechins, the least caffeine, and has a pale colour with a delicate, sweet taste. This tea is pale yellow or green in color $[7,8]$. The simplified steps of processing of white tea are summarised in Figure 1.

\section{Fresh tea leaf $\rightarrow$ Withering $\rightarrow$ Drying (air / solar / mechanical drying) $\rightarrow$ White tea}

Figure 1: Steps of processing of white tea. 
The dried leaves and buds used for preparation of white tea and the tea preparation prepared thereof is depicted in Figure 2 \& 3 .

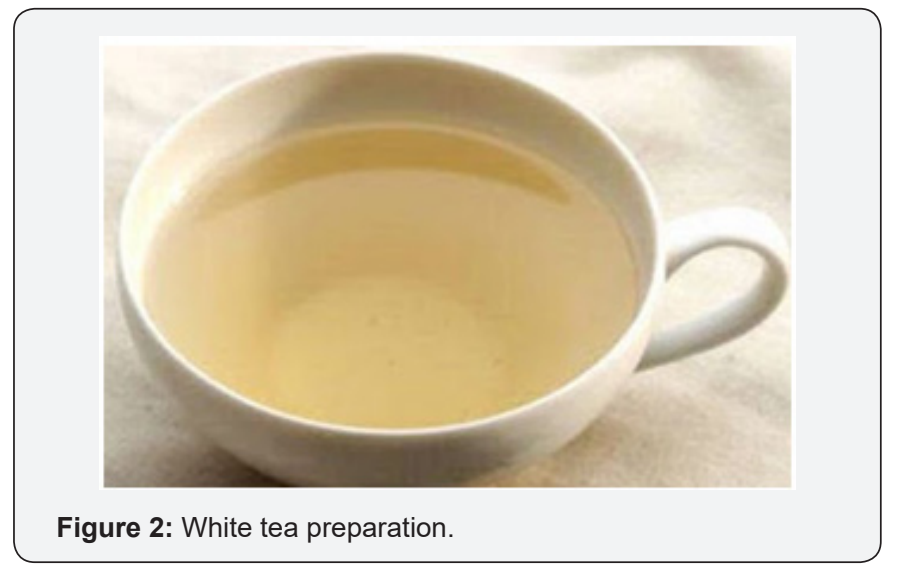

Figure 2: White tea preparation.

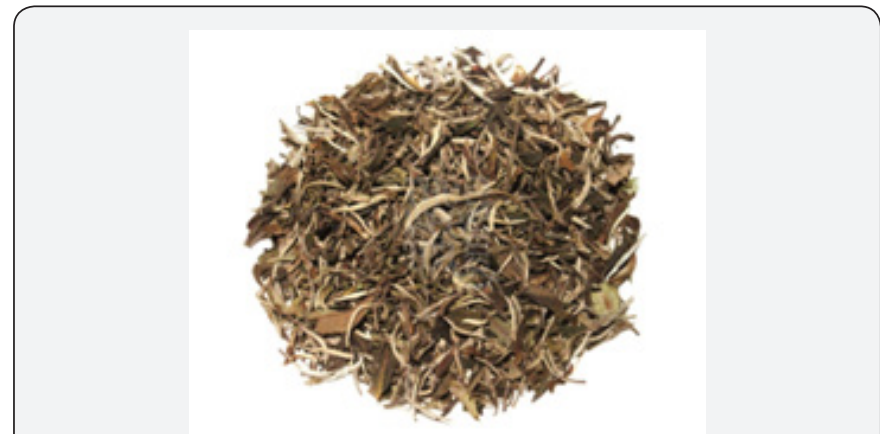

Figure 3: Dried leaves and bud of white tea.

\section{Chemical Composition of White Tea}

The main constituents of tea include proteins, polysaccharides, polyphenols, minerals and trace elements, amino and organic acids, lignin's, and methylxanthines (caffeine, theophylline, and theobromine). White tea contains about 3.35-5.74\% of caffeine, $16.23-25.95 \%$ of Polyphenol's, $0.06-1.44 \%$ of flavonol glycosides, and $7.94-16.56 \%$ of catechins. The major phenolic compounds present in tea leaves are catechins (also known as flavan-3-ols) and their derivatives, which constitute up to $30 \%$ of their dry weight. The chemical structure of Catechin is depicted in Figure 4.

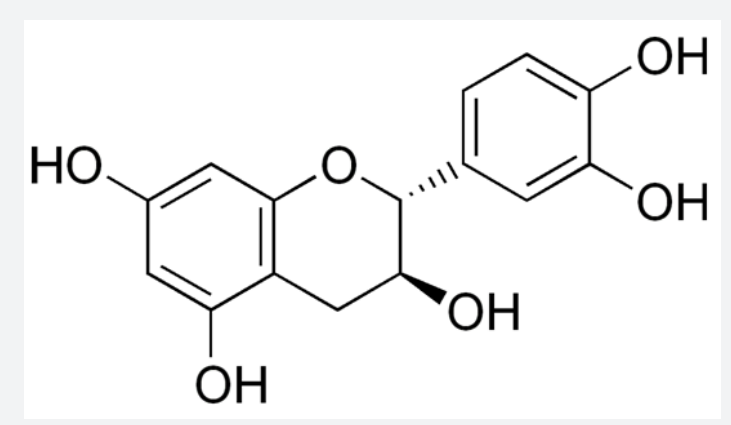

Figure 4: Chemical structure of Catechin.

The main catechins present in White tea are: (-)-epicatechin (EC), (-)-epigallocatechin (EGC), collectively known as flavanol monomers, (-)-epicatechin 3-gallate (ECG), and (-)-epigallocatechin 3-gallate (EGCG) (Figure 2), which are flavanol gallates [9-13].

\section{Comparison of Different Types of Teas}

The comparison of white tea with green and black tea is represented in Table $1[3,8]$.

Table 1: Comparison of white tea, green tea and black tea.

\begin{tabular}{|c|c|c|c|}
\hline Parameters & White Tea & Green Tea & Black Tea \\
\hline $\begin{array}{c}\text { Caffeine Content/ } \\
\text { Serving }\end{array}$ & \multirow{2}{*}{$15 \mathrm{mg}$} & \multirow{2}{*}{$40 \mathrm{mg}$} & \multirow{2}{*}{$20 \mathrm{mg}$} \\
\hline (Approximately) & & & \\
\hline $\begin{array}{c}\text { Total Polyphenols } \\
\text { / 100g }\end{array}$ & $16.23-25.95$ & $13.7-24.7$ & $8.3-24.8$ \\
\hline $\begin{array}{l}\text { Preparation } \\
\text { Procedure }\end{array}$ & $\begin{array}{c}\text { No } \\
\text { fermentation }\end{array}$ & $\begin{array}{c}\text { Short } \\
\text { fermentation }\end{array}$ & $\begin{array}{c}\text { Long } \\
\text { fermentation }\end{array}$ \\
\hline Taste & Sweet & $\begin{array}{l}\text { Sweet after } \\
\text { bitter }\end{array}$ & Bitter \\
\hline Colour & Pale yellow & Green or yellow & Red or black \\
\hline
\end{tabular}

\section{Biopotential/Health Benefits of White Tea}

The health benefits of white tea are summarized as below:

1. Tea catechins effectively reduce cholesterol absorption from the intestine, lowering the solubility of cholesterol and enhancing the faecal excretion of cholesterol and total lipids. It lowers bad cholesterol Low density lipoprotein (LDL) while enhances the levels of High density lipoprotein (HDL). Thus, it reduces hypertension, thereby prevents arteriosclerosis and improves heart and cardiovascular health $[14,15]$.

2. Numerous studies have demonstrated that tea catechins and polyphenols are effective scavengers of physiologically relevant reactive oxygen nitrogen species (RONS) in vitro, including superoxide, peroxyl radicals, singlet oxygen, peroxynitrite and hypochlorous acid. It is good for cardiovascular and circulatory systems $[16,17]$. It prevents heart strokes mainly due to the elimination free radicals due to its antioxidant property $[18,19]$.

3. Cancer is generally considered as uncontrolled cell division that results in the aggregation of cells to form tumours. It is one of the major causes of death in the modern world and has shown to be a largely preventable disease, highly susceptible to modulation by dietary factor's [20]. Flavonoids, another group of antioxidants found in white tea, are known to block the formation of carcinogenic cells and as such it prevents the cancerous growth in prostate, colon, intestine and stomach. Polyphenols present in tea may play an important role in prevention of cancer by decreasing DNA damage in the cell and reducing the activation of cancer that leads to malignancy [21]. Catechins also protect cell 
membranes against oxidation, keep RONS in confined zones and probably block cell membrane receptors required for cancer cell growth. The initiation of carcinogenesis can be overcome by the repression of some catalytic activities and of other specific enzymes involved in cancer initiation [22,23].

4. Diabetes mellitus (DM) is an increasingly common, potentially devastating, expensive, treatable but incurable lifelong disease. White tea is more likely to lower stress and glucose levels in the blood and helpful for increasing metabolism. Published reports show that numerous extracts obtained from plants are effective in reducing glycemia, causing fewer side effects and with lower cost than the usual antidiabetic agents. Recently, White tea was reported to have strong lipolytic and antiadipogenic activity in vitro. Hence, white tea may demonstrate antidiabetic effect by reducing oxygen species (OS) and hyperlipidaemia followed by insulin resistance. Since diabetes mellitus is increasing worldwide as is associated with several complications, there is a large interest in finding an effective therapy and white tea seems to be a good alternative. Furthermore, in-depth investigation is needed to fully understand the mechanisms of action of white tea against this disease $[24,25]$.

5. Tea also exhibits some antimicrobial properties, which are attributed mainly to its polyphenols. The degree of this activity depends on the bacterial species and the polyphenol structure. The antimicrobial activity of nonfermented tea is higher than that of semi-fermented or fermented tea. Moreover, the highest antimicrobial activity occurs in samples with the highest total polyphenol concentration and antioxidant activity [26-29]. The presence of tiny amounts of fluoride improves the health of gums and teeth by destroying bacteria [30].

6. White teas have been reported to possess higher antielastase, anti-collagenase, and antioxidative activity than certain green tea, suggesting its ability to promote strong and elastic skin and alleviate inflammation and rheumatoid arthritis [31]. It enhances the density of bones and prevents joint pains, softening of bones, and arthritis.

7. Although there are many proposed genetic and environmental factors that predispose individuals to weight gain, the fundamental cause of obesity is an imbalance between dietary intake and energy expenditure. The mechanisms of action of tea in obesity are: stimulation of hepatic lipid metabolism; inhibition of lipases; stimulation of thermogenesis; modulation of appetite; and synergism with caffeine. Simple tea drinking may have easier acceptance by the patients than prescription drugs, exercise and bariatric surgery. The main attractions of tea as an anti-obesity agent are that it is a more natural and safer alternative, there is no need for professional supervision and it is readily accessible and affordable [32-37].
8. White tea strengthens immune system as the antioxidants act against viruses and bacteria [38-40]. As it flushes out free radicals, it also improves skin health and slows down aging process.

\section{Recent Findings on White tea}

Recent research findings reported in the literature are summarized below [41]:

1. The anti-viral and anti-bacterial effect of white tea is greater than that of green tea.

2. The anti-viral and anti-bacterial effect of several toothpastes including Aim, Aqua fresh, Colgate, Crest and Orajel was enhanced by the addition of white tea extract.

3. White tea extract exhibited an anti-fungal effect on both Penicillium chrysogenum and Saccharomyces cerevisiae.

4. White tea extract may have application in the inactivation of pathogenic human microbes, i.e., bacteria, viruses, and fungi.

\section{Conclusion}

Dietary components influence prevalence of morbidity and mortality due to chronic disease. To prevent this, more amounts of antioxidants should be consumed in daily diet, which is readily available in a simple cup of white tea. Studies have shown that two to four cups of white tea per day yield great health benefits. Although a great deal of information has been accumulated on the effect of tea on cancer, a clear understanding of the mechanism by which tea components may affect the genesis, growth, and progression of specific cancers is essential. The bioavailability of tea polyphenols following tea consumption by the human population, studies on the absorption, distribution, and metabolism of green and black tea polyphenols in animals and humans are of utmost importance. It will be beneficial to carry out more research and long-term clinical trials in this promising area as tea is a common drink for many in many countries on a daily basis.

\section{References}

1. Polaskova P, Herszage J, Ebeler SE (2008) Wine flavor: Chemistry in a glass. Chem Soc Rev 37(11): 2478-2489.

2. Liu Y, Rousseaux S, Tourdot Maréchal R, Sadoudi M, Gougeon R (2015) Wine microbiome, a dynamic world of microbial interactions. Crit Rev Food Sci Nutr 57(4): 856-873.

3. Bokulich NA, Collins TS, Masarweh C, Allen G, Heymann, et al. (2016) Associations among wine grape microbiome, metabolome, and fermentation behavior suggest microbial contribution to regional wine characteristics. mBio 7(3): 00631-00616.

4. Bokulich NA, Thorngate JH, Richardson PM, Mills DA (2014) Microbial biogeography of wine grapes is conditioned by cultivar, vintage, and climate. Proc Natl Acad Sci USA 111(1): 139-148.

5. Zarraonaindia I, Owens SM, Weisenhorn P, West K, Hampton-Marcell J, et al. (2015) The soil microbiome influences grapevine-associated microbiota. mBio 6(2): 02527-02614. 
6. Gilbert JA, van der Lelie D, Zarraonaindia I (2014) Microbial terroir for wine grapes. Proc Natl Acad Sci USA 111(1): 5-6.

7. Belda I, Ruiz J, Alastruey Izquierdo A, Navascués E, Marquina D, et al. (2016) Unraveling the enzymatic basis of wine flavorome: a phylofunctional study of wine related yeast species. Front Microbiol 7: 12.

8. Álvarez Pérez JM, Campo E, San Juan F, Coque JJR, Ferreira V, et al. (2012) Sensory and chemical characterisation of the aroma of prieto picudo rosé wines: the differential role of autochthonous yeast strains on aroma profiles. Food Chem 133(2): 284-292.

9. Campbell Sills H, Capozzi V, Romano A, Cappellin L, Spano G, et al. (2016) Advances in wine analysis by PTR-ToF-MS: optimization of the method and discrimination of wines fermented with different malolactic starters. Int J Mass Spectrom 397-398: 42-51.

10. Bartowsky EJ (2005) Oenococcus oeni and malolactic fermentationmoving into the molecular arena. Aust J Grape Wine Res 11(2): 174187.

11. Du Toit M, Engelbrecht L, Lerm E, Weber K, Lactobacillus S (2011) The next generation of malolactic fermentation starter cultures-An overview. Food Bioprocess Technol 4(6): 876-906.

12. Berbegal C, Peña N, Russo P, Grieco F, Pardo I, et al. (2016) Technological properties of Lactobacillus plantarum strains isolated from grape must fermentation. Food Microbiol 57: 187-194.

13. Moreno Arribas MV, Polo MC (2005) Winemaking biochemistry and microbiology: Current knowledge and future trends. Crit Rev Food Sci Nutr 45(4): 265-286.

14. Munoz R, Moreno Arribas M, De las Rivas B (2011) Lactic acid bacteria. In molecular wine microbiology ( $1^{\text {st }}$ edn), Carrascosa AV, Muñoz $\mathrm{R}$, González R (Eds.), Elsevier Academic Press: London, UK, pp. 191-226.

15. Tao Y, García JF, Sun DW (2014) Advances in wine aging technologies for enhancing wine quality and accelerating wine aging process. Crit Rev Food Sci Nutr 54(6): 817-835.

16. Moreno Arribas V, Pueyo E, Polo MC (1996) Peptides in musts and wines. Changes during the manufacture of cavas (sparkling wines). J Agric Food Chem 44(12): 3783-3788.

17. Alcaide Hidalgo JM, Moreno Arribas MV, Martín Álvarez PJ, Polo MC (2007) Influence of malolactic fermentation, postfermentative treatments and ageing with lees on nitrogen compounds of red wines. Food Chem 103(2): 572-581.

18. Zeng XA, Yu SJ, Zhang L, Chen XD (2008) The effects of ac electric field on wine maturation. Innov Food Sci Emerg 9(4): 463-468.
19. Loira I, Vejarano R, Morata A, Ricardo da Silva J, Laureano O, et al. (2013) Effect of Saccharomyces strains on the quality of red wines aged on lees. Food Chem 139(1-4): 1044-1051.

20. Juega M, Carrascosa AV, Martinez Rodriguez AJ (2015) Effect of short ageing on lees on the mannoprotein content, aromatic profile, and sensorial character of white wines. J Food Sci 80(2): 384-388.

21. Belda I, Navascués E, Marquina D, Santos A, Calderón F, et al. (2016) Outlining the influence of non-conventional yeasts in wine ageing over lees. Yeast 33(7): 329-338.

22. Suárez R, Suárez Lepe J, Morata A, Calderón F (2007) The production of ethylphenols in wine by yeasts of the genera Brettanomyces and Dekkera: A review. Food Chem 102(1): 10-21.

23. Bachmanov AA, Bosak NP, Lin C, Matsumoto I, Ohmoto M, et al. (2014) Genetics of taste receptors. Curr Pharm Des 20(16): 2669-2683.

24. The Human Microbiome Project Consortium (2012) Structure, function and diversity of the healthy human microbiome. Nature 486(7402): 207-214

25. Boehlke C, Zierau 0, Hannig C (2015) Salivary amylase: the enzyme of unspecialized euryphagous animals. Arch Oral Biol 60 (8): 1162-1176.

26. Burdach KJ, Doty RL (1987) The effects of mouth movements, swallowing and spitting on retronasal odor perception. Physiol Behav 41(4): 353-356.

27. Genovese A, Piombino P, Gambuti A, Moio L (2009) Simulation of retronasal aroma of white and red wine in a model mouth system. Investigating the influence of saliva on volatile compound concentrations. Food Chem 114 (1): 100-107.

28. Bellman R, Gallander JF (1979) Wine deacidification. Advances in Food Research 25: 1-53.

29. Baliga S, Muglikar S, Kale R (2013) Salivary pH: a diagnostic biomarker. J Indian Soc Periodontol 17(4): 461-465.

30. Piombino P, Genovese A, Esposito S (2014) Saliva from obese individuals suppresses the release of aroma compounds from wine. Plos One 9(1): 85611.

31. Derrien M, Van Passel MWJ, Van De Bovenkamp JHB, Schipper RG, De Vos WM, et al. (2010) Mucin-bacterial interactions in the human oral cavity and digestive tract. Gut Microbes 1(4): 254-268.

32. Munoz Gonzales C, Cueva C, Angeles Pozo Bayòn M, Victoria Moreno Arribas M (2015) Ability of human oral microbiota to produce wine odorant aglycones from odourless grape glycosidic aroma precursors. Food Chem 187: 112-119.

\author{
Your next submission with Juniper Publishers \\ will reach you the below assets \\ - Quality Editorial service \\ - Swift Peer Review \\ - Reprints availability \\ - E-prints Service \\ - Manuscript Podcast for convenient understanding \\ - Global attainment for your research \\ - Manuscript accessibility in different formats \\ ( Pdf, E-pub, Full Text, Audio) \\ - Unceasing customer service \\ Track the below URL for one-step submission \\ https://juniperpublishers.com/online-submission.php
}

